\title{
Tatovering og MR-undersøkelse
}

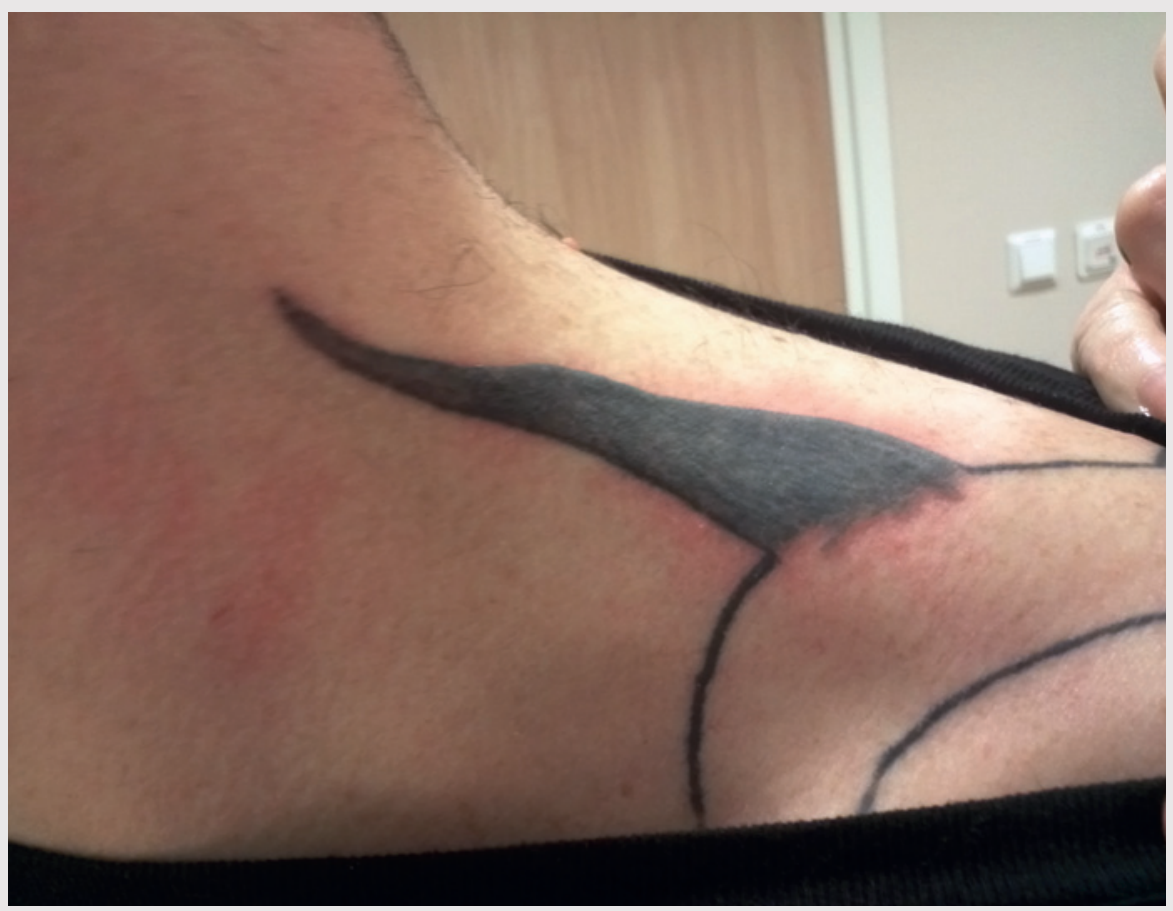

En mann i 30-årene med tallrike tatoveringer på truncus og ekstremiteter var til MRundersøkelse (1,5 tesla). Inne i MR-maskinen (ryggleie, armene ned langs kroppen) fikk han umiddelbart intense, sviende smerter i huden på venstre skulderparti og albueregion. Han ble uten opphold hentet ut av maskinen, og det ble konstatert ca. $2 \mathrm{~mm}$ hevelse av to tatoveringer på skulder/albue samt rubor omkring (bildet). Det ble forsøkt å gjenta undersøkelsen med lakenisolasjon mellom venstre overekstremitet og truncus, men samme smerter oppsto. Pasienten hadde undergått nesten identisk undersøkelse uten problemer én måned tidligere, men da i mageleie med armene over hodet (utenfor MR-tunellen).

Tatoveringene var utført i Skandinavia et par år tilbake, alle med samme teknikk og tatovør. Alt blekket var innkjøpt ved samme tatoveringsinstitutt, men $\mathrm{i}$ de to aktuelle tatoveringene var det benyttet en annen type blekk enn de øvrige.

Skader pga. tatovering i forbindelse med MR-undersøkelse opptrer en sjelden gang, da helst som reaksjoner tilsvarende førstegradsforbrenning (1). Trolig er det maskinens sterke hovedmagnet (øver magnetisk drag på metallpartiklene) samt gradientmagneter og radiofrekvenspulser (indusert oppvarming) som forårsaker skadene (2). I vårt tilfelle var bare hovedmagneten på (den er allid på), slik at reaksjonen sannsynligvis skyldtes magnetisk drag på jernpartiklene.

\section{Kristian Kolnes}

kristian.kolnes@gmail.com

Radiologisk avdeling

Volda sjukehus, Helse Møre og Romsdal

Pasienten har gitt samtykke til at artikkelen blir publisert.
Kristian Kolnes (f. 1967) er spesialist i radiologi og overlege ved Radiologisk avdeling, Volda sjukehus.

Forfatter har fylt ut ICMJE-skjemaet og oppgir ingen interessekonflikter.

\section{Litteratur}

1. Ross JR, Matava MJ. Tattoo-induced skin «burn» during magnetic resonance imaging in a professional football player: a case report. Sports Health: A Multidisciplinary Approach http://sph.sagepub.com/content/early/2011/06/10/ 1941738111411698 (4.7.2012).

2. Tope WD. Shellock FG. Magnetic resonance imaging and permanent cosmetics (tattoos): survey of complications and adverse events. J Magn Reson Imaging 2002; 15: 180-4. 